\title{
ANALISIS KEMAMPUAN KOMUNIKASI MATEMATIS BERDASARKAN GAYA BELAJAR VISUAL
}

\author{
Masrifah $^{1)}$, Rina Dwi Setyowati ${ }^{2}$, Nurina Happy ${ }^{3)}$ \\ 1,2,3) Universitas PGRI Semarang; \\ masrifah.tkj30@gmail.com
}

\begin{abstract}
This study aims to investigate the effect of the problem-based learning model and students' worksheets on the ability to understand mathematical concepts of learners. This is a quantitative study using a quasi-experimental with the nonequivalent type posttest only control group design. The population are all students of class VII SMP 174 Jakarta in the 2018/2019 school year. The samples are 71 students from classes VII-D and VII-G. The sampling technique is a cluster random sampling. Data collected using instruments of understanding mathematical concepts. The distribution of experimental and the control class are normal. Hypothesis testing produces a t-test of 1.9521, which is rejected $\mathrm{H} 0$ at a significance level of $5 \%$ with an effect size of 0.5343 which is classified as moderate. The results of this study indicate that there is an effect of the problem-based learning model based on student worksheets on the ability to understand mathematical concepts with moderate criteria.
\end{abstract}

Keywords. Mathematical communication skill, Visual learning style

\section{Pendahuluan}

Pendidikan merupakan suatu langkah awal untuk mengembangkan potensi yang dimiliki oleh seseorang. Dalam mengembangkan potensi diri dapat melalui upaya pengajaran. Menurut Sholihah (2015) salah satu bidang studi yang mempunyai peranan penting dalam dunia pendidikan dan dalam menghadapi masalah kehidupan sehari-hari adalah matematika. Seperti yang tercantum dalam Permendiknas Nomor 22 Tahun 2006 bahwa salah satu tujuan pembelajaran matematika yaitu mengomunikasikan gagasan mengenai objek-objek matematika. Dalam konteks ini, komunikasi yang dimaksud adalah komunikasi lisan/verbal dan komunikasi tertulis/ nonverbal. Selanjutnya, komunikasi tersebut disebut komunikasi matematis. Menurut Asikin yang dikutip Darkasyi (2014), komunikasi matematis dapat diartikan sebagai suatu dialog yang terjadi dalam suatu lingkungan kelas,

Euclid, p-ISSN 2355-1712, e-ISSN 2541-4453, Vol. 7, No. 1, pp. 1- 76

CLembaga Penelitian Universitas Swadaya Gunung Jati (UGJ), Cirebon. 
dimana terjadi pengalihan pesan. Pesan yang dialihkan berisi tentang materi matematika yang dipelajari di kelas. Penyampaian pesan atau materi oleh guru ke siswa ditujukan untuk saling berinteraksi, sehingga proses pembelajaran berjalan dengan lancar. Sebaliknya, komunikasi antara siswa dan guru yang tidak baik mengakibatkan rendahnya kemampuan komunikasi matematis.

Setiap siswa memiliki karakter yang berbeda dalam hal berkomunikasi. Sehingga, seorang guru hendaknya mengetahui masing-masing karakter siswanya sesuai dengan kemampuan siswa mengomunikasikan ide-ide matematisnya yang diduga berkaitan dengan cara atau gaya belajar siswa dalam menyerap, mengolah dan mengatur informasi yang diperolehnya pada pembelajaran. Menurut DePorter dan Hernacki (2005: 110) gaya belajar adalah kecenderungan seseorang dalam menerima, menyerap, dan memproses informasi.

Salah satu gaya belajar adalah gaya belajar visual. Gaya belajar visual adalah gaya belajar dengan cara melihat (DePorter \& Hernacki, 2005: 113), mengamati, memandang, dan sejenisnya (Papilaya dan Huliselan, 2016). Gaya belajar visual dilakukan seseorang untuk memperoleh informasi seperti melihat gambar, diagram, peta, poster, grafik, teks (tulisan dan huruf) dan sebagainya. Seorang yang bertipe visual, akan cepat mempelajari bahanbahan yang disajikan secara tertulis, bagan, grafik, dan gambar (Gilakjani dan Branch , 2012: 105).

Menurut Sari (2017) subjek bergaya belajar visual mampu dalam (1) mengeskpresikan ide-ide atau permasalahan melalui tulisan; menggunakan istilah, notasi, dan simbol matematika dalam menyajikan ide; (3) menginterpretasikan ide-ide atau permasalahan matematika dengan bahasa sendiri dan (4) menarik kesimpulan dari pernyataan matematika. Namun, tidak mampu menyatakan ide atau permasalahan matematika secara visual dalam grafik/diagram/tabel.

Berdasarkan uraian di atas, tujuan dari penelitian ini adalah mendeskripsikan kemampuan komunikasi matematis siswa yang memiliki gaya belajar visual. Kemampuan komunikasi matematis yang dimaksud adalah kemampuan komunikasi matematis tertulis berdasarkan gaya belajar visual untuk menyelesaikan soal-soal pada materi segitiga dan segiempat kelas VII SMP. Adapun aspek dan indikator kemampuan komunikasi tertulis

Euclid, p-ISSN 2355-1712, e-ISSN 2541-4453, Vol. 7, No. 1, pp. 1- 76 (CLembaga Penelitian Universitas Swadaya Gunung Jati (UGJ), Cirebon. 
yang digunakan dalam penelitian ini mengacu pada NCTM (2000)dapat dilihat pada Tabel 1.

Tabel 1. Aspek dan Indikator Kemampuan Komunikasi Matematis

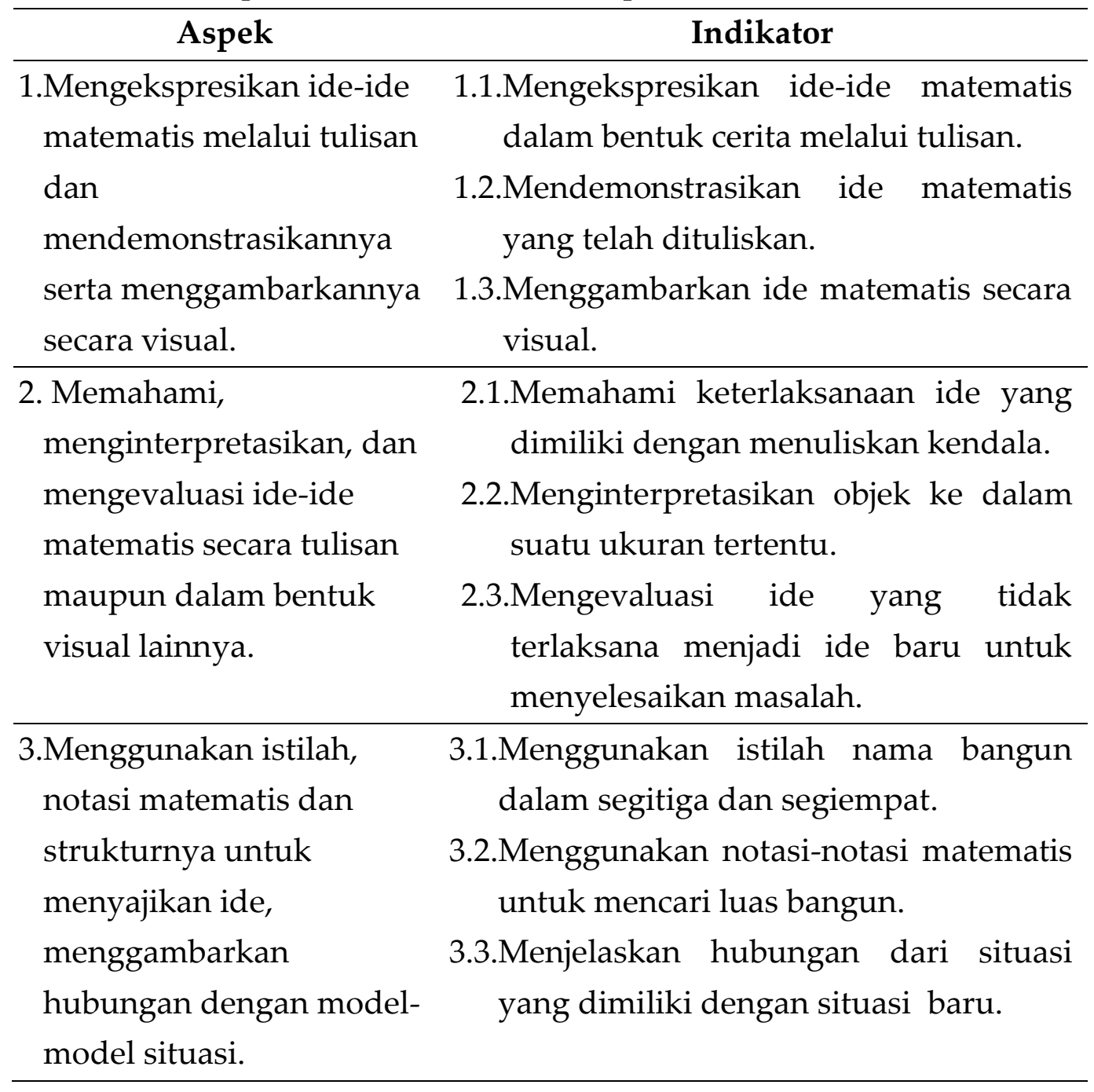

\section{Metodologi Penelitian}

Penelitian ini adalah penelitian kualitatif yang dilakukan di SMP N 28 Semarang. Penelitian ini dilakukan pada 30 April-13 Mei 2019 yang terdiri dari pemberian angket gaya belajar, pemilihan subjek penelitian, serta pemberian soal tes kemampuan komunikasi matematis terhadap subjek penelitian. Peneliti terlibat langsung dalam semua tahap penelitian. Instrumen yang digunakan adalah angket gaya belajar, dan lembar tes tertulis kemampuan komunikasi matematis yang masing-masing telah divalidasi oleh validator.

Euclid, p-ISSN 2355-1712, e-ISSN 2541-4453, Vol. 7, No. 1, pp. 1- 76

CLembaga Penelitian Universitas Swadaya Gunung Jati (UGJ), Cirebon. 
Penentuan subjek penelitian dilakukan dengan memberikan angket gaya belajar kepada siswa kelas VII F SMP N 28 Semarang pada tanggal 30 April 2019 yang berjumlah 32 siswa dan diperoleh hasil, yaitu: 12 orang bergaya belajar visual, 9 orang bergaya belajar auditorial, 5 orang bergaya elajar kinestetik, 3 orang bergaya belajar visual-auditorial, dan 3 orang tidak hadir saat pelaksanaan. Selanjutnya, dari 12 orang bergaya belajar visual dipilih yang memiliki nilai UTS matematika pada rentang 80-85. Hasil penelusuran dilihat pada tabel 2. Berdasarkan nilai UTS dan pertimbangan guru, terpilih subjek SP-V9 sebagai subjek penelitian.

Tabel 2. Nilai UTS Siswa dengan Gaya Belajar Visual

\begin{tabular}{llcllclcc}
\hline No & $\begin{array}{l}\text { Kode } \\
\text { Siswa }\end{array}$ & $\begin{array}{c}\text { Nilai } \\
\text { UTS }\end{array}$ & No & $\begin{array}{l}\text { Kode } \\
\text { Siswa }\end{array}$ & $\begin{array}{c}\text { Nilai } \\
\text { UTS }\end{array}$ & No & $\begin{array}{c}\text { Kode } \\
\text { Siswa }\end{array}$ & $\begin{array}{c}\text { Nilai } \\
\text { UTS }\end{array}$ \\
\hline 1. & SL-V1 & 52 & 5. & SL-V5 & 51 & 9. & SP-V9 & 81 \\
\hline 2. & SL-V2 & 43 & 6. & SL-V6 & 65 & 10. & SL-V10 & 49 \\
\hline 3. & SP-V3 & 41 & 7. & SL-V7 & 74 & 11. & SL-V11 & 45 \\
\hline 4. & SP-V4 & 38 & 8. & SP-V8 & 49 & 12. & SL-V12 & 48 \\
\hline
\end{tabular}

Setelah itu, peneliti menggunakan teknik tes, yaitu memberikan soal tahap pertama kepada subjek SP-V9 untuk mengetahui kemampuan komunikasi matematisnya pada tanggal 10 Mei 2019. Selanjutnya, pada tanggal 13 Mei 2019 dilakukan pemberian soal tes tahap. Peneliti juga melakukan dokumentasi. Setelah semua data terkumpul dilakukan analisis data dan triangulasi waktu untuk mendeskripsikan kemampuan komunikasi matematis siswa berdasarkan gaya belajar visual dengan membandingkan data yang diperoleh dari pengerjaan soal tahap pertama dan pengerjaan soal tahap kedua dengan waktu yang berbeda agar mendapatkan data yang kredibel (Sugiyono, 2017).

\section{Hasil Penelitian dan Pembahasan}

Hasil tes kemampuan komunikasi subjek SP-V9 pada aspek 1 disajikan pada tabel 3 sebagai berikut:

Tabel 3. Kemampuan komunikasi matematis subjek SP-V9 aspek 1 


\begin{tabular}{|c|c|c|}
\hline Indikator & Tahap 1 & Tahap 2 \\
\hline 1.1. & Subjek dapat menceritakan & Subjek dapat menceritakan \\
\hline Mengekspre & langkah yang dilakukan, yaitu: & langkah yang dilakukan, \\
\hline sikan ide- & a) 3 bangun jajargenjang & yaitu: a) 16 bangun segitiga \\
\hline & disusun di bawah kepala; b) 1 & sama kaki dan dijadikan \\
\hline matematis & buah trapesium untuk disusun & muka kepala beruang; b) 2 \\
\hline dalam & di atas jajargenjang; c) 1 buah & buah segitiga siku-siku \\
\hline bentuk & segitiga sama sisi dan 1 buah & disusun dibagian telinga \\
\hline cerita & persegi panjang diletakkan di & beruang sebelah kanan dan \\
\hline melalui & atas trapesium; d) segitiga & kiri; c) subjek membutuhkan \\
\hline tulisan. & sama kaki ditaruh dibagian & 2 buah segitiga siku-siku lagi \\
\hline & pipi kiri dan layang-layang di & untuk diletakkan dibagian \\
\hline & atas segitiga sama kaki; e) 2 & telinga beruang kanan dan \\
\hline & buah segitiga sama sisi & kiri, namun bangun yang \\
\hline & disusun menjadi telinga; $\mathrm{f}$ ) & dibutuhkan tidak ada dalam \\
\hline & Terdapat sisi yang belum terisi & model-model geometri yang \\
\hline & dan bangun tidak ter & tersedia. \\
\hline
\end{tabular}

Subjek SP-V9 dapat mengekspresikan ide-ide matematis dalam bentuk cerita melalui tulisan secara detail.

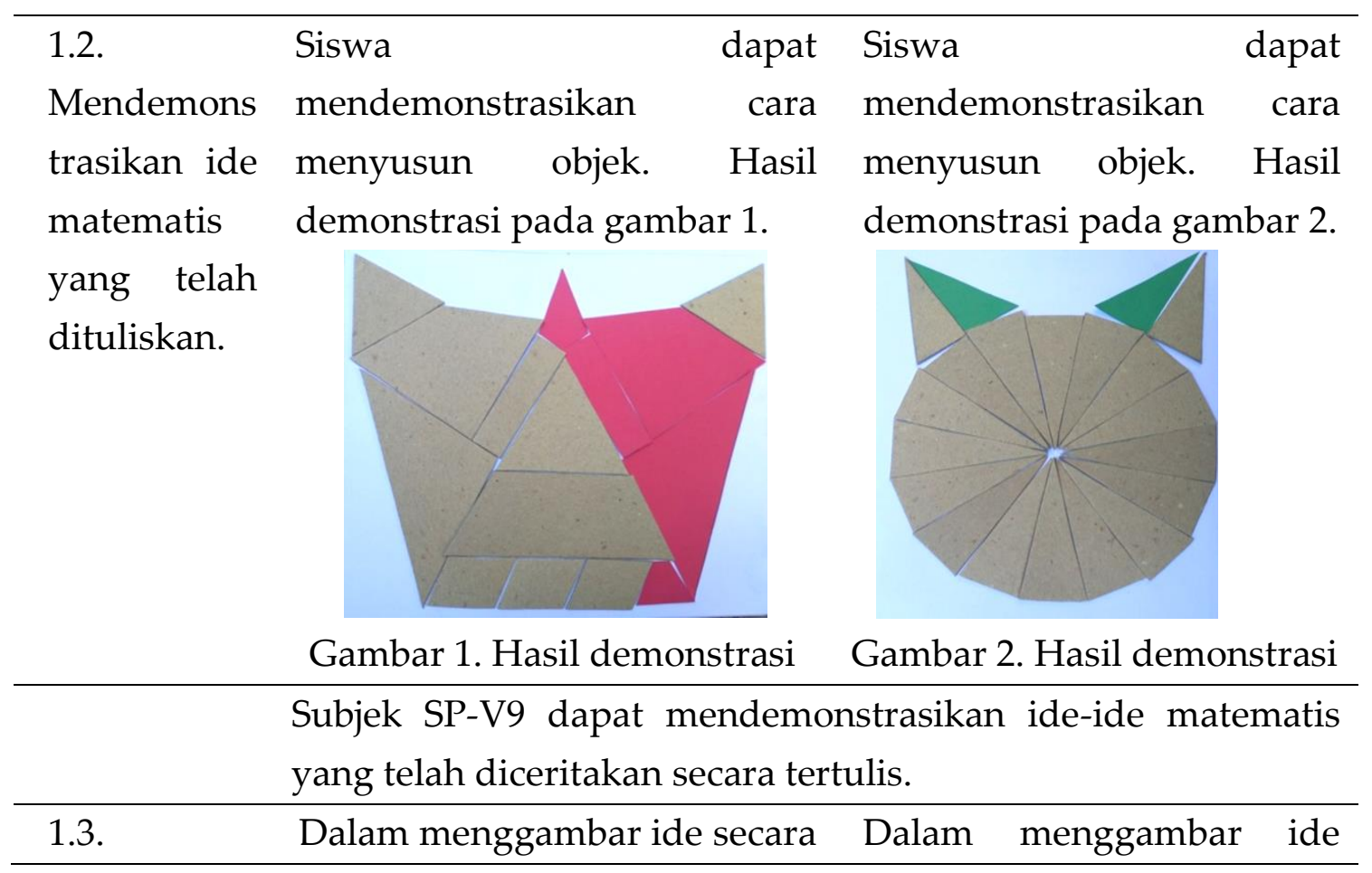


Aspek 1. Mengekspresikan ide-ide matematis melalui tulisan dan mendemonstrasikannya serta menggambarkannya secara visual.

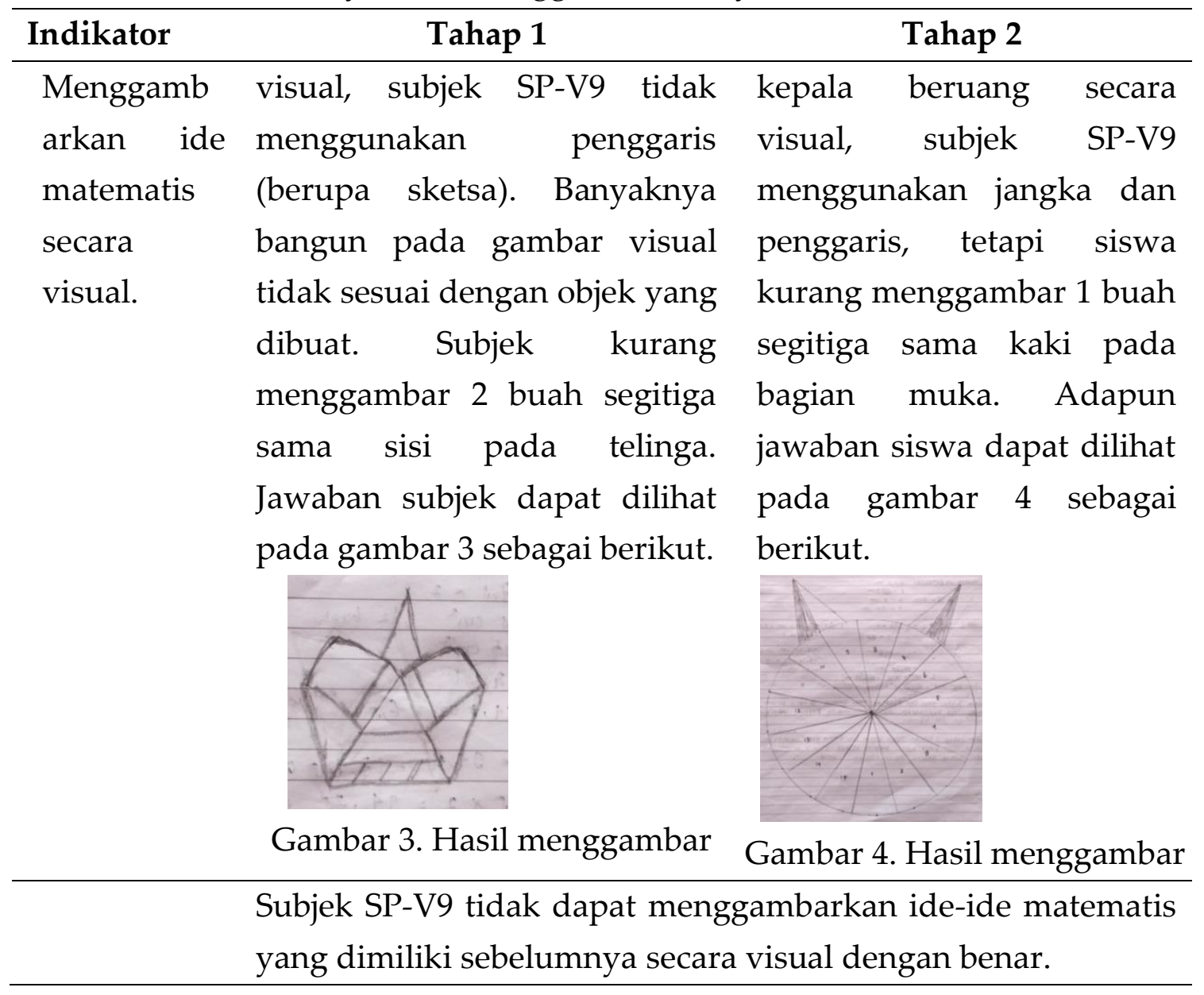

Secara umum, subjek SP-V9 dapat mengekspresikan ide-ide matematisnya dalam bentuk cerita melalui tulisan (indikator 1.1) secara detail, hal ini selaras dengan karakteristik seseorang dengan gaya belajar visual yaitu akan lebih teliti terhadap detail (DePorter \& Hernacki, 2005: 116). Subjek SP-V9 dapat menuliskan langkah mengekspresikan ide matematisnya dalam bentuk cerita. Hal ini sesuai dengan hasil penelitian Sari (2017) yaitu subjek dengan gaya belajar visual mampu dalam mengekspresikan ide-ide atau permasalahan matematika melalui tulisan. Dalam mendemonstrasikan ide matematis yang telah dituliskan (indikator 1.2), secara umum subjek SP-V9 dapat mendemonstrasikan ide-ide matematis yang telah dituliskan menjadi objek konkrit dengan baik. Namun, subjek SP-V9 tidak dapat menggambarkan ide matematis secara visual (indikator 1.3) yang ditunjukkan subjek SP-V9 tidak dapat menggambarkan objek konkrit 
menjadi gambar visual menggunakan penggaris sehingga membentuk gambar yang tidak sesuai dengan gambar saat mendemonstrasikan dan juga masih bangun yang digambar tidak komplit. Hal ini sesuai dengan penelitian Sari (2017) bahwa subjek gaya belajar visual tidak mampu menyatakan ide-ide atau permasalahan matematika secara visual.

Hasil tes kemampuan komunikasi subjek SP-V9 aspek 2 disajikan pada Tabel 4 sebagai berikut:

Tabel 4. Kemampuan komunikasi matematis subjek SP-V9 aspek 2

Aspek 2. Memahami, menginterpretasikan, dan mengevaluasi ide-ide matematis secara tulisan maupun dalam bentuk visual lainnya.

\begin{tabular}{|c|c|}
\hline Indi & Tahap 1 \\
\hline \multirow{7}{*}{$\begin{array}{l}\text { 2.1. Memahami } \\
\text { keterlaksanaan } \\
\text { ide dengan } \\
\text { menuliskan } \\
\text { kendala yang } \\
\text { dihadapi. }\end{array}$} & menyusun model Saat \\
\hline & SP-V9 geometri \\
\hline & memahami bangun yang memahami bangun yang \\
\hline & tersedia tidak dapat disusun ter \\
\hline & menjadi kepala panda dan me \\
\hline & butuh bangun tambahan. \\
\hline & $\begin{array}{l}\text { nahami idenya } \\
\text { ala yang diha }\end{array}$ \\
\hline \multirow{9}{*}{$\begin{array}{l}2.2 . \\
\text { Menginterpreta } \\
\text { sikan bangun } \\
\text { yang dibentuk } \\
\text { ke dalam suatu } \\
\text { ukuran } \\
\text { tertentu. }\end{array}$} & membutuhkan Sisı \\
\hline & minimal kertas \\
\hline & $26 \mathrm{~cm} \times 22 \mathrm{~cm}$ \\
\hline & gan mengukur der \\
\hline & menggunakan pe \\
\hline & penggaris panjang dan lebar lek \\
\hline & \\
\hline & SP-V9 c \\
\hline & \\
\hline 2.3 . & engevaluasi Sul \\
\hline Mengevaluasi & Iannya \\
\hline ang tidak & bangun menambahkan \\
\hline ksana & berwarna merah yaitu 1 menggunakan \\
\hline menjadi & segitiga berwarna hijau yaitu 2 buah \\
\hline
\end{tabular}




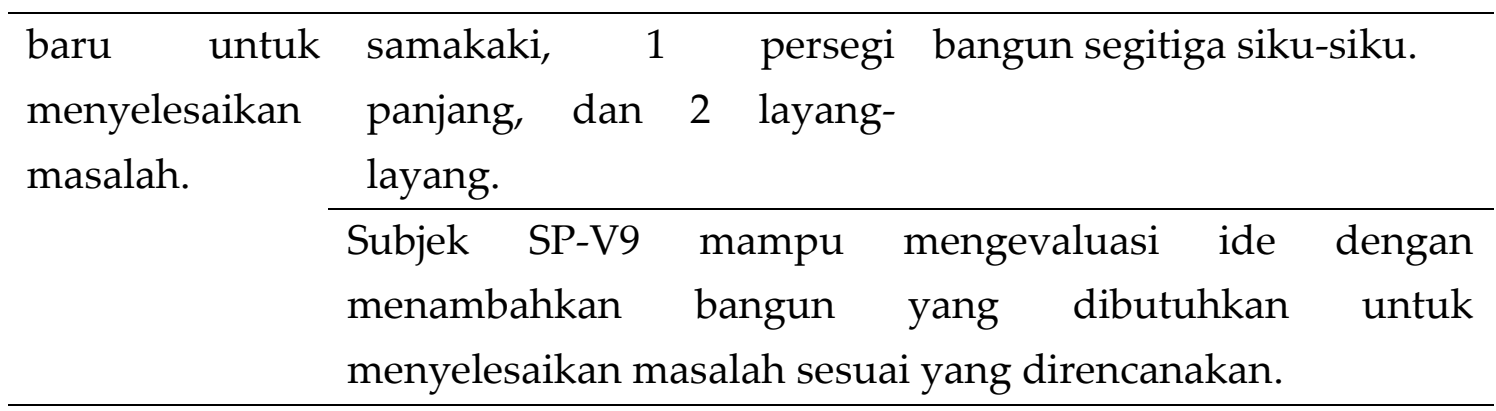

Subjek SP-V9 dapat memahami kendala yang dihadapi dengan menuliskan bangun yang dibutuhkan untuk melengkapi susunan yang sudah dibuatnya (indikator 2.1). Hal ini sesuai dengan Astuti (2017) yaitu kemampuan memahami dan menginterpretasikan ide-ide matematis melalui tulisan tergolong sangat baik karena siswa bergaya belajar visual mampu mengekspresikan ide-ide yang dimilikinya dengan rapi dan teratur sehingga siswa mampu menyelesaikan dan menjawab permasalahan dengan sangat baik. Pada indikator 2.2 subjek SP-V9 dapat menginterpretasikan ukuran minimal kertas yang dibutuhkan untuk bangun yang dibentuk dengan cara mengukur susunan bangun menggunakan penggaris. Hal ini sesuai dengan hasil penelitian Sari (2017) bahwa subjek dengan gaya belajar visual mampu dalam menginterpretasikan ide-ide atau permasalahan matematika dengan bahasanya sendiri. Selanjutnya pada indikator 2.3 yaitu mengevaluasi ide yang tidak terlaksana menjadi ide baru untuk menyelesaikan masalah, subjek SP-V9 dapat mengevaluasi ide dengan menambahkan bangun yang dibutuhkan untuk menyelesaikan masalah dengan membuat bangun tambahan menggunakan kertas yang disediakan peneliti. Hal ini sejalan dengan Astuti (2017) yaitu kemampuan mengevaluasi ide matematis secara tulisan siswa bergaya belajar visual tergolong baik karena siswa mampu menyelesaikan permasalahan dan dapat menuliskan jawaban dengan baik. Hasil tes kemampuan komunikasi subjek SP-V9 pada aspek 3 disajikan pada tabel 5 sebagai berikut.

Tabel 5. Kemampuan komunikasi matematis subjek SP-V9 pada aspek 3

Aspek 3. Menggunakan istilah-istilah, notasi-notasi matematis dan strukturstrukturnya untuk menyajikan ide-ide, menggambarkan hubungan-hubungan dengan model-model situasi.

Euclid, p-ISSN 2355-1712, e-ISSN 2541-4453, Vol. 7, No. 1, pp. 1- 76

(CLembaga Penelitian Universitas Swadaya Gunung Jati (UGJ), Cirebon. 
Subjek SP-V9 mampu menggunakan istilah nama bangun segitiga dan segiempat dengan benar (indikator 3.1) dengan menuliskan nama-nama bangun yang menyusun objek. Namun, subjek SP-V9 tidak dapat menggunakan notasi matematis untuk mencari luas bangun dan juga terdapat kesalahan dalam mengukur masing-masing bangun sehingga membuat ukuran luasnya salah (indikator 3.2). Hal ini sesuai dengan hasil penelitian Khairunnisa (2018) dimana subjek dengan gaya belajar visual memiliki kemampuan kurang baik pada saat menyatakan peristiwa seharihari dengan simbol-simbol matematika dalam menyajikan ide-ide matematik secara tertulis. Pada indikator 3.3 subjek SP-V9 mampu menjelaskan hubungan dari minimal kertas yang dibutuhkan dengan ukuran kertas yang terdapat dalam soal. Siswa dapat menyimpulkan kertas yang dibutuhkan untuk menyusun cukup atau tidak sesuai dengan ukuran kertas pada soal. Hal ini sesuai dengan hasil penelitian Sari (2017) bahwa subjek dengan gaya belajar visual mampu dalam menarik kesimpulan dari pernyataan matematika.

\section{Simpulan dan Saran}

Kemampuan komunikasi matematis berdasarkan gaya belajar visual sangat baik ditunjukkan dengan dapat menyelesaikan 7 indikator, yaitu: 1.1 mengekspresikan ide-ide matematis dalam bentuk cerita melalui tulisan, indikator 1.2 mendemonstrasikan ide matematis yang telah dituliskan, indikator 2.1 memahami ide yang dimiliki dapat terlaksana atau tidak dengan menuliskan kendala yang dihadapi, indikator 2.2 menginterpretasikan bangun yang dibentuk ke dalam suatu ukuran tertentu yang dibutuhkan, indikator 2.3 mengevaluasi ide yang tidak terlaksana menjadi ide baru untuk menyelesaikan masalah, indikator 3.1 menggunakan istilah nama bangun dalam segitiga dan segiempat, indikator 3.3 menjelaskan hubungan dari situasi yang dimiliki dengan situasi yang baru. Namun, tidak dapat menggambarkan ide matematis secara visual (indikator 1.3), dan menggunakan notasi-notasi matematis untuk mencari luas bangun (indikator 3.2).

Guru perlu memberikan kesempatan kepada siswa bergaya belajar visual untuk mengomunikasikan gagasannya dengan cara menyediakan penjelasan atau masalah dalam bentuk visual. 


\section{Daftar Pustaka}

Astuti, I. B. 2017. Analisis Kemampuan Komunikasi Matematis Ditinjau Dari Gaya Belajar Siswa Pada Materi Pola Bilangan Kelas VIII SMP N 2 Mranggen. Skripsi. Semarang: Universitas PGRI Semarang.

Darkasyi, M., Johar, R., Ahmad, A. 2014. Peningkatan Kemampuan Komunikasi Matematis Dan Motivasi Siswa Dengan Pembelajaran Pendekatan Quantum Learning Pada Siswa SMP Negeri 5 Lhokseumawe. Jurnal Didaktik Matematika, Vol. 1, No. 1, Hal. 21-34.

Depdiknas. 2006. Permendiknas Nomor 22 Tahun 2006 Tentang Standar Isi Sekolah Menengah Atas. Jakarta: Depdiknas.

DePorter, B \& Hernacki, M. 2005. Quantum Learning. Bandung: Kaifa.

Gilakjani, A.P., \& Branch, L. 2012. Visual, Auditory, Kinaesthetic Learning Styles and Their Impact of English Language Teaching. Journal of Studies Education, Vol.2, No.1. Hal. 104-113. Tersedia di http://brainbutter.com.au/wp/wpcontent/uploads/2013/01/ VisualAuditory-Kinaesthetic-.pdf [diakses 6 desember 2018].

Khairunnisa. 2018. Analisis Kemampuan Komunikasi Matematis Ditinjau Dari Gaya Belajar Siswa Kelas VIII MTs S Islamiyah Urung Pane. Skripsi.Universitas Islam Negeri Sumatera Utara Medan.

NCTM. 2000. Principles and Standards for School Mathematics. USA: NCTM.

Osterholm, M. 2006. Metakognition and reading-criteria for comprehension of mathematics texts. In Novotna, J., Moraova, H.Kratka, M.\& Stehlikova, N. (Eds.). Proceeding 30th Conference of the International Group for the Psychology of Mathematics Education, Vol. 4, pp.289-296.Prague: PME.

Papilaya, J. O., Huliselan, N. 2016. Identifikasi Gaya Belajar Mahasiswa. Jurnal Psikologi Undip, Vol. 15, No. 1. Hal. 56-63.

Sari, Ika. P. 2017. Kemampuan Komunikasi Matematika Berdasarkan Perbedaan Gaya Belajar Siswa Kelas X SMA Negeri 6 Wajo Pada Materi Statistika. Jurnal Nalar Pendidikan, Vol. 5, No. 2, hal. 88-89.

Sholihah, Dyahsih. A. 2015. Keefektifan Experiential Learning Pembelajaran Matematika MTs Materi Bangun Ruang Sisi Datar. Jurnal Riset Pendidikan Matematika, Vol.2-Nomor 2, hal. 175-185.

Sugiyono. 2017. Metode Penelitian Pendidikan Pendekatan Kuantitatif, Kualitatif dan RED. Bandung: Alfabeta.

Euclid, p-ISSN 2355-1712, e-ISSN 2541-4453, Vol. 7, No. 1, pp. 1- 76

CLembaga Penelitian Universitas Swadaya Gunung Jati (UGJ), Cirebon. 